\title{
Spatial Concentration in the U.S. Auto Supplier Industry
}

\author{
Thomas H. Klier*
}

\begin{abstract}
This paper investigates the spatial characteristics of auto supplier plant locations in the U.S. in light of the industry's adoption of just-in-time manufacturing methods. The issue of agglomeration is investigated for 3,137 independent supplier plants that were in operation during 1997. The industry is found to be highly spatially concentrated, with Michigan, Indiana, Ohio, Kentucky, and Tennessee representing the preferred location choice of independent auto supplier plants. Within that region, however, domestic and Japanese suppliers concentrate in the northern and southern half, respectively. Each group tends to locate closer to assembly plants of the same nationality.
\end{abstract}

\section{INTRODUCTION}

This paper investigates the spatial characteristics of auto supplier plant locations in the U.S. in light of the industry's adoption of just-in-time (or lean) manufacturing methods, such as efforts to keep inventories low and reduce the number of parts suppliers. The issue of agglomeration is investigated at the industry level based on the spatial characteristics of 3,137 independent supplier plants that were in operation during 1997.

Since lean manufacturing was pioneered by Toyota Motor Company in the 1950s, it has become the standard practice of many manufacturing companies in Japan and around the world. This production system tries to improve on the type of mass production systems that have been prominent in the postwar period. Instead of organizing production according to a preset schedule, lean manufacturing operates on the premise of a so-called "pull system," whereby the flow of materials and products through the various stages of production is triggered by the customer. In addition, the production process itself is subject to continuous improvement efforts. The GM strike during June and July of 1998, when the UAW struck two GM parts plants in Flint, MI, and within three weeks idled 26 of 29 of GM's North American light vehicle assembly plant facilities plus nearly 100 parts plants, showed the extent to which lean manufacturing production methods have taken hold in the U.S. auto sector (see Bradsher 1998).

What effects had the emphasis on just-in-time relationships across the supply chain on the spatial structure of plant locations in the manufacturing sector? It has been argued that efforts to reduce inventory stocks and arrange for "just-in-time" delivery function most effectively where the supplying and receiving plants are in reasonably close proximity (Estall 1985; Kenney and Florida 1992;

*Federal Reserve Bank of Chicago. The author would like to thank Neil Murphy, Michael Rorke, and George Simler for excellent research assistance as well as three anonymous referees for their suggestions. The views expressed in this paper are those of the author and do not necessarily reflect opinions of either the Federal Reserve Bank of Chicago or the Federal Reserve System. 
Mair 1992; Dyer 1994). The concomitant increase in the frequency of interaction and communication between assembler and supplier companies is expected to strengthen that effect further. On the other hand, there is some evidence that spatial clustering is not a necessary condition for the successful operation of lean manufacturing (Woodward 1992; Lilley and DeFranco 1999). That is because existing transportation infrastructure in combination with state-of-the-art delivery management might well be able to provide predictability of arrival time, even with very frequent deliveries, with no significant increase in clustering of supplier plants around downstream customers. ${ }^{1}$

\section{THEORY}

The standard argument for observing localization of industry goes back to Alfred Marshall (1920). He identified three reasons for location of industry at an industrial center: first, it allows a pooled labor market for workers with specialized skills; second, it provides nontraded inputs specific to an industry in greater variety and at lower cost; and third, it generates technological spillovers as information flows more easily locally.

This paper disaggregates the location pattern of a specific industry and addresses the question of how location decisions at the plant level are influenced by characteristics of the manufacturing system. According to Weber's (1928) location theory model, a plant chooses its location in order to minimize the sum of transportation and production costs, given the location of its customer(s). Within such a framework, implementation of lean manufacturing production techniques is expected to put greater importance on transportation costs as a result of more frequent deliveries and smaller lot sizes, since parts now need to be delivered to where they are needed on relatively short notice rather than being delivered to inventory. What is unclear is if that effect is large enough to affect the plant location choice, resulting in suppliers' (re)locating closer to their assembly plant customers. In particular, productivity increases in the transportation sector combined with the existing stock of transportation infrastructure might keep the spatial effects of lean manufacturing rather small. In addition to just-in-time downstream linkages, one might expect parts and plant characteristics to influence the supplier's location decision. For example, for parts that disproportionately impact inventory costs, such as bulky items or items of high value, lean manufacturing is expected to pull the supplier plant close to its customer. On the other hand, plants that operate with large economies of scale need to serve multiple customers from one production facility and are therefore likely to locate towards the spatial center of all their customers.

\footnotetext{
${ }^{1}$ Furthermore, evidence from other industries and other countries indicates that the magnitude of the effect of lean manufacturing on location varies by industry and by country (see Andersen Consulting 1994; Dyer 1994; and Jones and North 1991). For example, the Andersen Consulting (1994) study of 71 auto parts plants in nine countries suggests that Japan's auto industry is characterized by the most geographically concentrated supply base, with 82 percent of the suppliers located within a four-hour journey by truck from the assembly plant. In contrast, the percentages for the U.S., U.K., and Germany are 35, 53, and 52, respectively.
} 


\section{REVIEW OF PREVIOUS EVIDENCE}

The issues of geographic concentration in U.S. manufacturing have of late received increasing attention (see Hewings, Israilevich, and Schindler 1998; Ellison and Glaeser 1997; Kim 1995; and Krugman 1991). Krugman (1991) argues that external economies or increasing returns to scale have a pervasive influence on the economy. In doing so they give a decisive role to history in determining the geography of economies. In discussing the uneven development of regions, Krugman (1991) illustrates his argument with a model of periphery and core. He makes the point that agglomeration is based on externalities that result from market size effects in the presence of transportation costs. Kim (1995) utilizes data from 1860 through 1987 to calculate indices of regional specialization as well as industrial location. He argues that the historical trends in regional specialization for U.S. industry can be explained jointly by models based on scale economies and resources. Ellison and Glaeser (1997) model the location of manufacturing plants as a function of random effects, localized spillovers, and natural advantages. In the empirical part of the paper they report evidence for both natural advantageand spillover-based agglomeration. Hewings, Israilevich, and Schindler (1997) find strong evidence of industry clusters at the regional level based on their analysis of 1993 commodity flow statistics.

Several studies have documented trends in plant location choices for the U.S. auto industry (see Rubenstein 1992, 1997 and McAlinden and Smith 1993). They find that since the mid-1970s the assembly plants for light vehicles have reconcentrated in the Midwest and the southeast region of the country. According to Rubenstein, this change in location pattern can be explained by changes in transportation cost economics facing the industry. Originally, assembly plants were built close to population centers as it was cheaper to ship parts to assembly plants than to ship finished vehicles across the country. Since the 1960s, however, the growth of the number of different models offered in the marketplace has far outstripped the growth of sales, turning the tables in favor of locating assembly plants in the heart of the country. In doing so, assembly companies could minimize the cost of distributing the final product to a national market. In that context it is not surprising that most of the coastal assembly plants were shut down during the last 20 years. In turn, the auto corridor's share of light vehicle assembly plants has increased from 47 percent to 67 percent between 1979 and 1996.

Plant location trends in the supplier industry are not as clear-cut. There has been a migration of labor-intensive parts production to the South and south of the border, starting as early as the 1960s. However, parts production requiring highly skilled labor, such as the production of engines and transmissions and large stampings, has remained heavily concentrated in the Midwest. That is especially true for parts plants operated by the auto assemblers themselves (so-called captive suppliers). These plants tend to be of older vintage, have large employment, and remain concentrated in lower Michigan and northern Indiana and Ohio. 
A set of studies specifically investigates possible effects of lean manufacturing on the spatial structure of the auto supplier industry. Most of the existing analysis of the location effects of lean manufacturing, however, concerns Japaneseowned manufacturing establishments within the U.S. This is not surprising, as these plants are generally set up to meet the demands of lean manufacturingbased assembly plants. In addition, most of them represent new plants established at newly developed, so-called greenfield sites. As the location decision for these plants does not involve a relocation, it makes them a preferred object of study.

Both Kenney and Florida (1992) and Reid (1994) find support for very local clustering effects among Japanese manufacturing plants. Woodward (1992), Lilley and DeFranco (1999), and Klier (forthcoming) point to the importance of transportation infrastructure and suggest that clustering occurs at a more regional scale instead. Smith and Florida (1994) present evidence of the location of the primary customer influencing plant location as well. They find that Japaneseaffiliated automotive suppliers prefer to locate in proximity to Japanese automotive assemblers.

\section{DATA}

The basis for the data analyzed in this study is the ELM Guide supplier database, a set of plant-level data on the auto supplier industry put together by a private company in Michigan. ${ }^{2}$ The data represent the year 1997 and cover 3,425 independent supplier plants located in the U.S. ${ }^{3}$ Based on information on the plants' customers, the individual supplier plants were classified into two groups: 1) 2,008 plants were found to be tier 1 suppliers, i.e., supplier plants that ship their products exclusively to auto assembly plants and not to other supplier plants or other customers; and 2) 1,292 were classified as mixed-tier suppliers, i.e., supplier plants that ship their products to other supplier plants and/or nonautomotive assemblers as well as auto assembly plants. Fifty observations had to be excluded from the analysis, as they did not provide information on which customer(s) to which they were shipping.

Several variables were then added to the database. Information on foreign ownership was obtained from industry press as well from the Japan Auto Parts Industries Association (1998) (see Table 1 for an ownership breakdown of the industry). Information on the plant's start-up year was obtained for only the tier 1 plants from various state manufacturing directories and the plants. In tracking establishment dates for these plants, about 8 percent of the 2,008 plant records as provided by the database could not be verified and are therefore not included in the subsequent analysis. The remainder of the paper presents information both on the spatial characteristics of the full set of 3,137 plant records, as well on the 1,845 tier 1 plants. These 1,845 plants represent the subset of supplier plants that is most closely linked to the auto assembly plants by way of production and delivery. One

\footnotetext{
${ }^{2}$ It identifies for each of these the address, the list of products produced as well as the production processes used, employment, and the plants' customers (at the company level).

${ }^{3}$ The analysis presented here does not include the captive supplier plants, i.e., parts plants operated by the auto assembler.
} 
would therefore expect to find any agglomeration effects related to lean manufacturing in this industry subset.

\section{TABLE 1}

Auto Supplier Industry by Ownership, 1997

\begin{tabular}{lcc}
\hline & \% of Plants in U.S. & \% of Employment \\
\hline Domestic & 84.7 & 81.6 \\
Foreign Owned & & \\
$\quad$ Japanese & 9.6 & 11.2 \\
$\quad$ Other & 5.7 & 7.2 \\
\hline
\end{tabular}

Note: calculations are based on 3,137 independent supplier plants open in 1997.

Numbers do not include Big Three supplier plants. Industry employment: 901,343 jobs.

Source: ELM International, Inc. (1997) and author's calculations.

\section{LOCATION PATTERN OF INDEPENDENT SUPPLIER PLANTS}

Table 2 presents the distribution of the 3,137 independent supplier plants included in the database. It shows auto supplier plants and employment to be highly spatially concentrated in the Midwest, with about 50 percent of all plants (and 40 percent of all employment) located in just three states: Michigan, Ohio, and Indiana. Light vehicle assembly plants are similarly concentrated in the middle of the country, with Michigan, Ohio, and Indiana being home to 45 percent of all plants (Ward's 1998). ${ }^{4}$

\section{TABLE 2}

Spatial Distribution of Auto Supplier Industry, 1997

\begin{tabular}{lcc}
\hline State & $\begin{array}{c}\text { \% of Independent } \\
\text { Supplier Plants }\end{array}$ & \% of Employment \\
\hline Illinois & 6.9 & 6.8 \\
Indiana & 9.1 & 10.1 \\
Kentucky & 4.0 & 4.1 \\
Michigan & 26.8 & 19.2 \\
Ohio & 13.2 & 11.2 \\
Tennessee & 4.7 & 5.8 \\
Wisconsin & 3.6 & 3.1 \\
& & \\
Midwest & auto corridor & \\
Aut & 59.6 & 50.4 \\
U.S. $^{\text {S.S. }}$ & 100.0 & 50.2 \\
\hline
\end{tabular}

Note: calculations are based on 3,137 independent supplier plants open in 1997.

Numbers do not include Big Three supplier plants. Industry employment: 901,343 jobs.

a Midwest is defined as Illinois, Indiana, Michigan; Ohio, and Wisconsin.

${ }^{b}$ Auto corridor consists of Indiana, Kentucky, Michigan, Ohio, and Tennessee.

However, it is important to keep in mind that this information represents plants from rather different vintages. For example, the oldest supplier plants in the sample date from the late 1800s: 38 plants opened prior to 1900 . Table 3 presents an age-specific distribution of the tier 1 suppliers included in Table 2. It shows that the Midwest's share of the industry fell from 61 percent to 56 percent in comparing plants established prior to 1980 with plants established after 1980.

${ }^{4}$ Incidentally, Ellison and Glaeser (1997) find the largest co-agglomeration among U.S. manufacturing industries for the following upstream-downstream industry pairs: 1) motor vehicle parts and accessories (SIC 3714) and motor vehicles and car bodies (SIC 3711); and 2) automotive stampings (SIC 3465) and motor vehicles and car bodies (SIC 3711). 
The observed increase in the auto corridor's share of plants is attributable to growth in Indiana and, especially, Kentucky and Tennessee. ${ }^{5}$

\section{TABLE 3}

Distribution of Tier 1 Supplier Plants

\begin{tabular}{|c|c|c|c|c|}
\hline \multirow[b]{2}{*}{ State } & \multicolumn{2}{|c|}{$\%$ of Tier 1 Supplier Plants } & \multicolumn{2}{|c|}{$\%$ of Tier 1 Employment } \\
\hline & $<1980$ & $>1979$ & $<1980$ & $>1979$ \\
\hline Illinois & 7.3 & 4.0 & 7.1 & 3.2 \\
\hline Indiana & 8.4 & 11.2 & 9.4 & 13.6 \\
\hline Kentucky & 1.7 & 6.9 & 1.8 & 7.7 \\
\hline Michigan & 28.1 & 26.3 & 20.5 & 21.9 \\
\hline Ohio & 14.2 & 12.2 & 11.3 & 10.3 \\
\hline Tennessee & 2.8 & 7.7 & 4.6 & 8.4 \\
\hline Wisconsin & 3.6 & 2.9 & 2.8 & 2.1 \\
\hline Midwest $^{\mathrm{a}}$ & 61.6 & 56.6 & 51.1 & 51.1 \\
\hline Auto corridor ${ }^{b}$ & 55.1 & 64.3 & 47.6 & 61.9 \\
\hline U.S. & 100.0 & 100.0 & 100.0 & 100.0 \\
\hline $\mathrm{N}$ & 1,016 & 829 & 329,706 & 216,978 \\
\hline
\end{tabular}

Source: ELM International, Inc. (1997) and author's calculations.

${ }^{a}$ Midwest is defined as Illinois, Indiana, Michigan, Ohio, and Wisconsin.

${ }^{\mathrm{b}}$ Auto corridor consists of Indiana, Kentucky, Michigan, Ohio, and Tennessee.

Incidentally, while the supplier industry has historically been spatially concentrated, the emergence of the auto corridor represents a fairly recent phenomenon. Utilizing Census data, one can observe how the spatial extension of SIC 3714, motor vehicle parts and accessories, has evolved over the last 50 years (see Table 4). Remarkably, the definition of SIC 3714, the "core" of the auto supplier industry, has changed very little over that time period. ${ }^{6}$ Between 1937 and 1992 the industry grew tremendously, from 936 to 3,246 establishments. During the same time its locational pattern has changed from an east-west extension, including New York and Pennsylvania in 1937, to a marked north-south extension reaching from Michigan all the way to Texas. In other words, this long-term comparison indicates not only the continued existence of agglomeration at the industry level but also suggests a noticeable change in the extension of the supplier region.

Focusing on the auto corridor in more detail, Figures 1 and 2 reveal different location patterns for domestic and Japanese-owned tier 1 supplier plants that opened between 1980 and 1997. Both figures focus on the five states of the auto corridor and show the presence of one (indicated by a triangle) or more (indicated by a circle) supplier plants within one zip code. Figure 1 shows the distribution of domestic tier 1 suppliers and the location of domestic light vehicle assembly

${ }^{5}$ The data at hand are purely cross sectional and do not allow for a time series analysis of plant openings. However, in breaking out the distribution of establishment year by state the pattern reported in Table 3 turns out to be very robust. Most of the observed change in plant location patterns for surviving plants does occur after 1980 , as 44 percent of the tier 1 plants in the data set opened during that time period.

${ }^{6}$ What is now referred to as SIC 3714 , motor vehicle parts and accessories, in 1937 was named "motor-vehicle bodies and motor-vehicle parts." While the current definition is more detailed, the extent of overlap is remarkable. According to the definitions listed in the respective Census publications, today's definition does not include the production of car bodies or automotive glass; conversely, the 1987 definition includes hoods, whereas the 1937 definition does not. However, Census data are not directly comparable to the data used in this paper, as they cannot focus on original equipment producers. It has been suggested that the prominence of California in Table 4 is due to the inclusion in SIC 3714 of establishments that rebuild engines on a factory basis. 
plants open in 1997. Figure 2 shows Japanese-owned supplier and assembly plants. Both maps also show the relevant parts of the existing interstate highway transportation infrastructure.

TABLE 4

Distribution of Establishments in SIC 3714

\begin{tabular}{cccc}
\hline \multicolumn{2}{c}{ 1937 Census } & \multicolumn{2}{c}{1992 Census } \\
State & \% of Establishments & State & \% of Establishments \\
\hline MI & 16.0 & CA & 13.9 \\
CA & 11.9 & MI & 13.4 \\
NY & 11.2 & OH & 7.6 \\
IL & 8.9 & IN & 6.7 \\
OH & 8.7 & TX & 5.3 \\
PA & 6.4 & IL & 4.1 \\
IN & 6.0 & TN & 3.4 \\
& 69.1 & & \multicolumn{2}{c}{$\mathrm{N}=3,246$} \\
\hline
\end{tabular}

Source: U.S. Department of Commerce (1937a, 1937b, 1992).

\section{FIGURE 1}

Plant Openings by Domestic Tier 1 Suppliers within Auto Corridor, 1980-1997

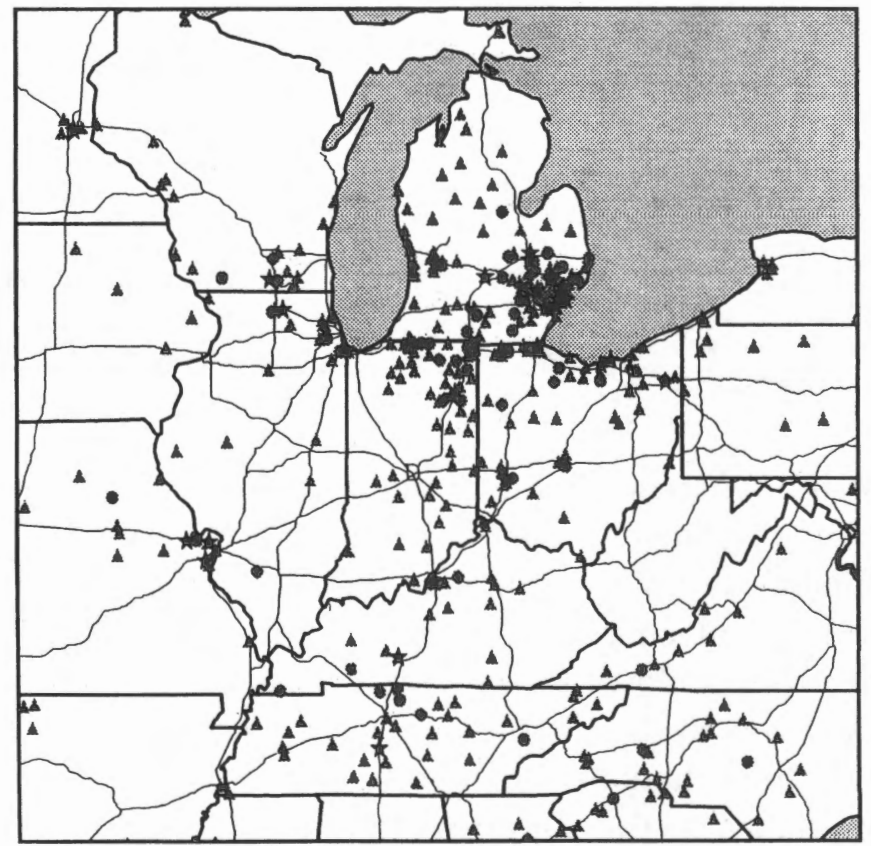

$\star$ Domestic Assembly Plant

1 Supplier Plant

- 2 or More Supplier Plants Interstate Highway

One can see that Japanese-owned suppliers primarily locate in the southern part of the automotive corridor (that is, Ohio, Kentucky, and Tennessee), whereas domestic suppliers concentrate in the northern part (Michigan, Indiana, and Ohio), with Ohio being the only state chosen prominently by both domestic and Japanese-owned supplier plants. The average latitude/longitude coordinates are $-84.4^{\circ}$ and $41.1^{\circ}$ for domestic suppliers and $-84.8^{\circ}$ and $39.0^{\circ}$ for Japanese suppliers. In other words, the centroid of the distribution of the Japanese supplier 
plants is located almost due south of the centroid of the distribution of domestic supplier plants. However, the dispersion of the individual plants around the respective centroids is very similar for both groups: the standard deviations of latitude and longitude for both point patterns are $1.58^{\circ}$ and $2.27^{\circ}$ for domestic suppliers and $1.18^{\circ}$ and $2.14^{\circ}$ for Japanese suppliers. In addition, proximity to the highway infrastructure seems to be equally important for both groups of plants.

FIGURE 2

Plant Openings by Japanese-Owned Tier 1 Suppliers within Auto Corridor, 1980-1997

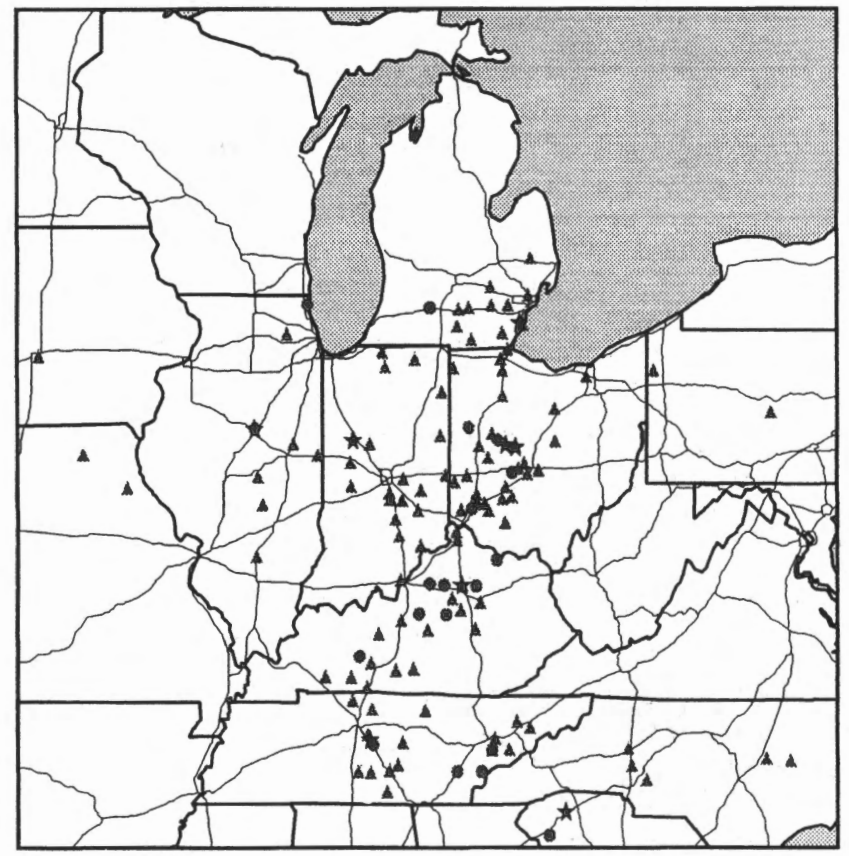

$\star$ Foreign Assembly Plant

A 1 Supplier Plant

- 2 or More Supplier Plants

- Interstate Highway

What then explains the difference in the north-south extension of the two point patterns? Is it that Japanese-owned suppliers respond differently to lean manufacturing conditions than domestic suppliers or is it simply a difference in the distribution of assembly plant customers? Unfortunately, the data do not allow for identification of product flows to individual customers. However, it allows us to focus on differences in the distribution of domestic and Japaneseowned assembly plants. If the nationality of the assembly plant customer is important for the location choice of the supplier plant, one would expect the domestic (Japanese) suppliers to be concentrated around domestic (Japanese) assembly plant facilities. ${ }^{7}$ Table 5 provides information on the distribution of supplier plants by nationality of customer. It presents data on domestic suppliers that supply only to Big Three assembly plants as well as data on Japanese-owned suppliers that do not supply to any Big Three assembly plants. Table 5 reports, indeed,

${ }^{7}$ See Smith and Florida (1994), who find evidence that Japanese-affiliated automotive suppliers prefer to locate in proximity to Japanese automotive assemblers. Reid, Solocha, and $O$ hUallachain (1995) suggest that this serves to minimize risk and uncertainty associated with establishing operations in the U.S. 
evidence of a "customer" effect, as each subgroup of supplier plants with a specific customer mix is more concentrated at one end of the auto corridor. ${ }^{8}$ Over 60 percent of domestic suppliers shipping only to domestic assembly plants are located in Michigan, Indiana, and Ohio, versus 52.6 percent of all domestic suppliers. Conversely, 64 percent of Japanese suppliers not shipping to any of the Big Three assembly plants are located in the southern half of the auto corridor, versus 52.6 percent of all Japanese suppliers. A comparison of the centroids of the distribution of auto corridor assembly and supplier plants for the two groups of interest suggests the same explanation. ${ }^{9}$ While domestic and Japanese suppliers both respond very similarly to spatial demands of lean manufacturing, they also want to be located close to their main assembly plant customers. It is the difference in the location patterns of assembly plants to which the location pattern of supplier plants is related.

TABLE 5

Percent of Tier 1 Suppliers Opened in Auto Corridor, 1980-1997

\begin{tabular}{|c|c|c|c|c|c|c|}
\hline \multicolumn{4}{|c|}{ Domestic } & \multicolumn{3}{|c|}{ Japanese Owned } \\
\hline & & & Supplying & & & Not Supplying \\
\hline & State & Overall & Only to Big 3 & State & Overall & to $\mathrm{Big} 3$ \\
\hline & MI & $31.3 \%$ & $40.0 \%$ & $\mathrm{OH}$ & $20.8 \%$ & $28.6 \%$ \\
\hline & IN & 10.9 & 11.4 & KY & 18.5 & 21.4 \\
\hline & $\mathrm{OH}$ & 10.4 & 10.2 & TN & 13.3 & 14.3 \\
\hline & TN & 6.3 & 4.2 & IN & 11.0 & 12.9 \\
\hline & $\underline{\mathrm{KY}}$ & 4.1 & 1.8 & MI & 9.2 & 0.0 \\
\hline & Top 3 & 52.6 & 61.6 & Top 3 & 52.6 & 64.3 \\
\hline $\begin{array}{l}\text { Number } \\
\text { of plants }\end{array}$ & & 607 & 166 & & 173 & 70 \\
\hline
\end{tabular}

Source: ELM International, Inc. (1997) and author's calculations.

Finally, it has been suggested earlier that parts characteristics influence the location decision of supplier plants. In order to address that, Table 6 reports on a measure of localization for nine different auto parts. They were chosen to represent a mix of characteristics relevant for the economics of transporting them, such as high value/low weight (sensors), economies of scale in production (tires), bulkiness (axles and transmissions), and variety (seats and wheels). For each of these, the distance between each of the parts plants in the database and every light vehicle assembly plant operational in the U.S. in 1997 (56 plants) was calculated. This algorithm generates a metric of the spatial distribution of supplier plants in relation to the distribution of assembly plants. Table 6 reports two values of the distribution of distances generated by this exercise: the median of all the shortest distances and the median of the average of the closest three distances between a supplier plant and the assembly plants. It shows the importance of a part's value-to-weight

\footnotetext{
${ }^{8}$ There were too few observations for the following two categories to be reported in the table: 1 ) domestic suppliers not supplying to Big Three assembly plants (16 plants); and 2) Japanese suppliers only supplying to Big Three facilities ( 9 plants). However, in both cases the evidence is consistent with Table 5 . Plants in these two categories are noticeably less concentrated in the most frequently chosen three states (31.2 percent for the domestic supplier plants and 33.3 percent for the Japanese-owned plants).

${ }^{9}$ The average latitude/longitude of domestic assembly plants located in the auto corridor is $-85.4^{\circ}$ and $41.0^{\circ}$ (That compares to $-84.4^{\circ}$ and $41.1^{\circ}$ for the domestic supplier plants). The same measures for Japanese assembly plants are $-84.9^{\circ}$ and $39.0^{\circ}$ (that compares to $-84.8^{\circ}$ and $39.0^{\circ}$ for Japanese suppliers).
} 
ratio to locating the production facility. As transportation costs have become more important in locating facilities in a lean manufacturing environment, bulky parts or parts with a low value-to-weight ratio are now less economical to ship across long distances. Take the evidence on seat plants. According to both localization measures, Table 6 lists by far the shortest distances between seat plants and assembly plants. In addition, seats are a good example of a part that comes in many different varieties. It therefore needs to be produced in tight synchronicity with the production schedule of the assembly plant in order to keep inventory low. This combination of bulkiness and variety results in plant locations close to the assembly plant customer. Similarly, the location of transmission and axle plants, both very bulky items, further support the importance of transportation costs for plant location. In contrast, the spatial distribution of sensor plants is much more dispersed. The database identifies 21 different types of sensors used in light vehicles, representative of the growing electronic content in today's vehicles. The production of these high-value but low-weight items is very much dispersed, with concentrations of plants in the auto corridor as well as on both coasts (Silicon Valley as well as the Boston area).

TABLE 6

Localization of Supplier Plants by Selected Parts

\begin{tabular}{lcc}
\hline Part & $\begin{array}{c}\text { Median Distance } \\
\text { to Closest Assembler }\end{array}$ & $\begin{array}{c}\text { Median Distance } \\
\text { to Closest 3 Assemblers }\end{array}$ \\
\hline Seats & 23.4 miles & 58.3 miles \\
Transmissions & 37.0 & 64.0 \\
Axles & 40.0 & 63.3 \\
Air conditioning & 50.5 & 82.5 \\
Wheels & 52.3 & 102.0 \\
Carpets & 57.7 & 88.9 \\
Valves & 58.8 & 87.6 \\
Sensors & 60.5 & 112.5 \\
Tires & 81.7 & 133.2 \\
\hline
\end{tabular}

Source: ELM International, Inc. (1997) and author's calculations.

The location of tire plants, listed at the bottom of Table 6 , suggests the relevance of economies of scale at the plant level. The 24 tire plants in the database report very large average employment of 1,500 , versus an industry average employment of 287. The underlying economies of scale in tire production result in the observed location pattern: locations in the center of the country, not particularly close to individual customers.

\section{CONCLUSION}

By refining a commercially available database, this paper presents a detailed look at the spatial distribution of independently owned auto supplier plants located in the U.S. It documents the geographic concentration of this industry and supports earlier findings about regional agglomeration of supplier plants in the automotive corridor that is defined by I-65 in the west and I-75 in the east. For supplier plants of recent vintage the five auto corridor states (Michigan, Indiana, Ohio, Kentucky, and Tennessee) overwhelmingly represent the preferred 
location choice.

Within that region, however, domestic and Japanese-owned supplier plants concentrate in the northern and southern half, respectively. That apparent difference is explained by differences in the distribution of domestic and Japanese assembly plants in the auto corridor. In other words, this paper finds no evidence of the location choices of either group of supplier plants being influenced differently by the lean manufacturing production system.

Furthermore, disaggregating the industry location pattern along characteristics of the parts produced shows their influence on plant location. For example, the production of parts that disproportionately impact inventory costs, such as bulky items or items of high value, is located close to the assembly plant.

The paper shows assembly and supplier plants to be concentrated in the same region of the country. The region's well-established highway transportation infrastructure seems to accommodate manufacturing system-related demands to closer integrate the supply chain physically and organizationally, while providing the ability to serve multiple customers from one location. Very tight clustering around assembly plants is observed only for very specific parts, such as seats.

\section{REFERENCES}

Andersen Consulting. Worldwide Manufacturing Competitiveness Study - The Second Lean Enterprise Report, 1994.

Bradsher, Keith. "GM Strike Spreads to Communities Far from Flint Factories." The New York Times, 29 June 1998, p. A1.

Dyer, Jeffrey H. "Dedicated Assets: Japan's Manufacturing Edge." Harvard Business Review 72 (November-December 1994), 174-178.

Ellison, Glenn, and Edward L. Glaeser, "Geographic Concentration in U.S. Manufacturing Industries: A Dartboard Approach." Journal of Political Economy 105 (1997), 889-927.

ELM International, Inc. The ELM GUIDE Supplier Database. East Lansing, MI, 1997. Estall, R.C. "Stock Control in Manufacturing: The Just-In-Time System and its Locational Implications." Area 17 (1985),129-132.

Hewings, Geoffrey J.D., Philip R. Israilevich, and Graham R. Schindler. "Interstate Trade among Midwest Economies." Chicago Fed Letter. Federal Reserve Bank of Chicago, May 1998.

Japan Auto Parts Industries Association. Membership Directory.1998.

Jones, Philip N., and John North. "Japanese Motor Industry Transplants: The West European Dimension." Economic Geography 67 (1991), 105-123.

Kenney, Martin, and Richard Florida. "The Japanese Transplants - Production Organization and Regional Development." Journal of the American Planning Association 58 (1992), 21-38.

Kim, Sukkoo. "Expansion of Markets and the Geographic Distribution of Economic Activities: The Trends in U.S. Regional Manufacturing Structure, 1860-1987." Quarterly Journal of Economics 110 (1995) 881-908. 
Klier, Thomas. "Does 'Just-In-Time' Mean Right-Next-Door? Evidence from the Auto Industry on the Spatial Concentration of Supplier Networks." Journal of Regional Analysis and Policy. Forthcoming.

Krugman, Paul. Geography and Trade. Cambridge, MA: MIT Press, 1991.

Lilley, William III, and Laurence DeFranco. The Impact of the European Grands Prix.

Geneva: Federation Internationale de l'Automobile, 1999.

Mair, Andrew. "Just-In-Time Manufacturing and the Spatial Structure of the Automobile Industry: Lessons from Japan." Tijdschrift voor Economische en Sociale Geografie 82 (1992), 82-92.

Marshall, Alfred. Principles of Economics. London: Macmillan, 1920.

McAlinden, Sean, and Brett Smith. The Changing Structure of the U.S. Automotive Parts Industry. UMTRI 93-6. Ann Arbor: University of Michigan Transportation Research Institute, 1993.

Reid, Neil. "Just-In-Time Inventory Control and the Economic Integration of JapaneseOwned Manufacturing Plants with the County, State and National Economies of the United States." Regional Studies 29 (1994), 345-355.

Reid, Neil, Andrew Solocha, and Breandán Ó hUallacháin. "Japanese Corporate Groups and the Locational Strategy of Japanese Auto and Component Parts Makers in the United States." In Milford B. Green and Rod B. McNaughton (eds.) The Location of Foreign Direct Investment. Aldershot, UK: Avebury, 1995. Rubenstein, James M. “The Evolving Geography of Production - Is Manufacturing Activity Moving out of the Midwest? Evidence from the Auto Industry." Assessing the Midwest Economy Working Paper SP-3. Federal Reserve Bank of Chicago, 1997.

The Changing U.S. Auto Industry - A Geographical Analysis. London: Routledge, 1992.

Smith, Donald, and Richard Florida. "Agglomeration and Industrial Location: An Econometric Analysis of Japanese-Affiliated Manufacturing Establishments in Automotive-Related Industries." Journal of Urban Economics 36 (1994), 23-41.

U.S. Department of Commerce. Bureau of the Census. Census of Manufactures. Washington, D.C., 1992.

. Census of Manufactures. Washington, D.C., 1937a.

. Maps of Selected Industries Reported at the Census of Manufactures. Washington, D.C., $1937 \mathrm{~b}$.

Ward's Communications. Ward's Automotive Yearbook. Overland Park, KS, 1998.

Weber, Alfred. Alfred Weber's Theory of Location of Industries. Translated by C.J. Friedrich. Chicago: University of Chicago Press, 1928.

Woodward, Douglas P. "Locational Determinants of Japanese Manufacturing Start-Ups in the United States." Southern Economic Journal 58 (1992), 690-708. 